\title{
Temperature and salinity effects on elemental uptake in the shells of larval and juvenile softshell clams Mya arenaria
}

\author{
Carly A. Strasser*, Lauren S. Mullineaux, Simon R. Thorrold \\ Biology Department, Woods Hole Oceanographic Institution, Woods Hole, Massachusetts 02543, USA
}

\begin{abstract}
The chemical composition of biogenic carbonate has great potential to serve as a natural tag in studies of marine population connectivity. Yet the degree to which carbonate chemistry reflects ambient water composition may be influenced by environmental parameters, physiology, and uptake kinetics. We explored the effects of temperature and salinity on the uptake of elements into shells of larval and juvenile softshell clams Муа arenaria. Clams were reared under controlled conditions using combinations of temperatures $\left(15,20\right.$, and $24^{\circ} \mathrm{C}$ ) and salinities (22 and $30 \%$ ) commonly encountered in their natural habitat. We analyzed the ratios of a suite of elements ( $\mathrm{Mg}, \mathrm{Mn}, \mathrm{Sr}, \mathrm{Ba}$ and $\mathrm{Pb}$ ) to $\mathrm{Ca}$ in seawater and shells using solution-based inductively coupled plasma-mass spectrometry (ICP-MS). Elemental ratios were translated into discrimination coefficients $\left(D_{\text {element }}\right)$ to account for water chemistry variability among treatments. For larval shell, we found that $\mathrm{D}_{\mathrm{Mn}}$ was lower in the low-temperature treatment than at higher temperatures, had mixed results for correlations with salinity, and exhibited an interactive effect between salinity and temperature. We also found that $\mathrm{D}_{\mathrm{Ba}}$ of larval shell was higher in the $15^{\circ} \mathrm{C}$ treatment than at the other 2 temperatures. In juvenile shell, we found a temperature effect for $D_{M n}$, however the exact relationship was unclear because $\mathrm{D}_{\mathrm{Mn}}$ was higher in the mid-temperature treatment than either the low- or high-temperature treatments. $\mathrm{D}_{\mathrm{Sr}}$ was negatively correlated with salinity in juveniles, with evidence of an interactive effect for temperature and salinity. $\mathrm{D}_{\mathrm{Ba}}$ and $\mathrm{D}_{\mathrm{Pb}}$ were both higher in juveniles in the low-temperature treatment than in the 2 higher temperatures. When discrimination coefficients significantly differed based on ANOVA, we used post hoc comparisons to further explore the effects of temperature and salinity. Correlation analyses showed that uptake differed significantly between larval and juvenile M. arenaria shell for all elements, with no predictable relationship in shell uptake between the 2 stages except for $\mathrm{D}_{\mathrm{Ba}}$. All of the elements examined in this study have the potential to be useful in tagging studies where geographic variability in temperature, salinity or elemental concentrations exists, although caution should be used to ensure any biological interactions with these variables are accounted for in data interpretation.
\end{abstract}

KEY WORDS: Mya arenaria - Bivalve shell - Elemental uptake - Discrimination coefficients · Temperature $\cdot$ Salinity $\cdot$ Larva $\cdot$ Biogenic carbonate

\section{INTRODUCTION}

Most marine benthic invertebrate life cycles include a planktonic larval phase that facilitates dispersal among adult populations (Thorson 1950). Connectivity, or the degree to which geographically separated populations exchange individuals, is an important factor in the spatial population dynamics of many marine organisms (Moilanen \& Nieminen 2002). Connectivity and spatial dynamics of marine benthic populations may play an important role in new fisheries management approaches, including the design and implementation of marine protected areas (Palumbi 2003, Shanks et al. 2003). However, studying larval dispersal 
(and therefore its role in connectivity) is challenging due to small larval sizes, rapid dilution rates, and high larval mortality (Thorson 1950, 1966).

In recent years, the use of artificial and natural tags to track marine larvae has been explored (e.g. Thorrold et al. 2002, Levin 2006). One type of natural tag that may be useful for identifying natal origins is the elemental signature recorded in biogenic carbonate. This technique relies on the observation that some elements are incorporated into the calcium carbonate matrix in amounts related to dissolved concentrations or physical properties of the ambient water (e.g. Bath et al. 2000, Vander Putten et al. 2000, Elsdon \& Gillanders 2003). Provided water chemistry or temperature is significantly different between natal habitats, such variation can serve as a natural tag, or signature, of the geographic origin of organisms. The use of geochemical signatures in fish otoliths as natural tags for population studies is well established (Campana 1999, Campana \& Thorrold 2001). Recent efforts have expanded the use of elemental tags to invertebrates including decapods (DiBacco \& Levin 2000), gastropods (Zacherl et al. 2003a), bivalves (Becker et al. 2005, 2007), and cephalopods (Arkhipkin et al. 2004, Zumholz et al. 2007).

Although biogenic carbonate composition may reflect elemental concentrations of waters where it was formed, additional factors are known to influence elemental uptake (Dodd 1967, Wilbur 1972). Environmental conditions, such as temperature, salinity, oxygen levels, and nutrient load, may alter a direct relation between environmental and carbonate composition. Also, physiological and biochemical factors may affect the signature, including differences in uptake between species or between stages within a species. These factors may potentially act in combination, thereby complicating a simple relationship between ambient elemental concentration and carbonate composition. Understanding the role each factor plays in determining carbonate chemistry is critical to the appropriate design and interpretation of studies that use natural elemental signatures as a proxy for geographic origins or to reconstruct environmental conditions.

Our ultimate goal is to develop elemental signatures in shell as tags of natal habitat for the softshell clam Mya arenaria, a commercially important bivalve commonly found in New England estuaries. In this study, we measured $\mathrm{Mg}: \mathrm{Ca}, \mathrm{Mn}: \mathrm{Ca}$, $\mathrm{Sr}: \mathrm{Ca}, \mathrm{Ba}: \mathrm{Ca}$, and $\mathrm{Pb}: \mathrm{Ca}$ in larval and juvenile shells of $M$. arenaria reared in the laboratory under controlled temperature and salinity. The results will improve our understanding of environmental effects on elemental uptake and therefore allow us to interpret variability in elemental signatures more effectively. Temperature and salinity are likely to vary on small time scales in estuaries (Bowden 1980) and are known to influence elemental uptake into biogenic carbonate.

First, we investigated larval shells to determine how the relationship between elemental composition of seawater and shell varied with temperature and salinity. Many studies have detailed the various factors controlling elemental compositions of fish otoliths (e.g. Fowler et al. 1995, Hoff \& Fuiman 1995, Bath et al. 2000, Arai et al. 2003, Bath Martin et al. 2004) and adult mollusc shells (e.g. Rucker \& Valentine 1961, Dodd 1965, Lerman 1965, Dodd \& Crisp 1982, Pitts \& Wallace 1994, Lazareth et al. 2003, Zacherl et al. 2003b). For mollusc larvae, however, shell uptake has been examined only in 1 gastropod (Zacherl et al. 2003b) and in no bivalves. We explored the relationships between temperature and salinity and $\mathrm{Mg}: \mathrm{Ca}$, $\mathrm{Mn}: \mathrm{Ca}, \mathrm{Sr}: \mathrm{Ca}, \mathrm{Ba}: \mathrm{Ca}$, and $\mathrm{Pb}: \mathrm{Ca}$ based on the demonstrated utility of these elements in previous uptake experiments.

Second, we investigated juvenile shells to determine how the relation between elemental composition of seawater shell varied with temperature and salinity, and compared the uptake into shells of larval and juvenile clams to look for predictable correlations. The physiological aspects of shell formation in larval and juvenile bivalves are likely to vary due to morphological differences in these 2 life stages. Although the mantle (or the precursor to the mantle, the shell gland) is responsible for shell production in both larval and post-larval clams, there are drastic changes in the tissue during development that might result in differences in shell composition. The differences between larval and juvenile shell composition may offer insight into the physiological factors potentially affecting elemental incorporation into shell. If temperature or salinity affects incorporation of elements into carbonate, investigators may need to consider these factors when interpreting environmental variables based on shell chemistry.

\section{MATERIALS AND METHODS}

Clam rearing. Adult Mya arenaria were obtained from Cotuit, Massachusetts, USA, in April 2006 and were transported to the Environmental Systems Laboratory (ESL) at Woods Hole Oceanographic Institution, where they were placed in mesh bags and suspended in a 7501 tank with filtered seawater. Spawning activity commenced approximately $1 \mathrm{~h}$ later and the tank was left undisturbed to allow spawning to finish and for fertilization to take place. After $5 \mathrm{~h}$ the adult clams were removed and the tank contents were filtered through a $35 \mu \mathrm{m}$ nylon mesh sieve to concentrate the larvae into a small volume ( 20 1). We subsampled and 
counted larvae to obtain a total estimate of 16 million trochophore larvae. Although polyspermy due to the high ratio of sperm to eggs was evident, most larvae were well formed and regular in appearance and behavior.

Trochophore larvae were placed into one of twentyfour 121 high-density polyethylene (HDPE) tanks at a density of 45 larvae $\mathrm{ml}^{-1}$. The tanks were divided among 6 treatments representing all combinations of 2 salinities (22.5 and 30\%; hereafter low and high) and 3 temperatures $\left(15,20\right.$, and $\left.24^{\circ} \mathrm{C}\right)$, with 4 replicate tanks per treatment combination. These temperatures and salinities represent the range of conditions experienced by Mya arenaria during the summer months in its natural estuarine habitats. Treatment temperatures were maintained by placing tanks in large water baths. Water baths for the 15 and $20^{\circ} \mathrm{C}$ treatments received a continuous supply of 15 and $20^{\circ} \mathrm{C}$ water, respectively, regulated for the seawater supply line by industrial chillers and heaters. The water bath for $24^{\circ} \mathrm{C}$ treatment tanks was maintained using a $120 \mathrm{~V}$ tank heater regulated by a thermostat (Process Technology EasyPlug ${ }^{\mathrm{TM}}$ Heater with Digital Controller, 1800 W). Seawater for all tanks was obtained from the in-house seawater supply line, which pumps water from Vineyard Sound, $100 \mathrm{~m}$ offshore of ESL at a water depth of $4 \mathrm{~m}$. All seawater was filtered to remove particles $>1 \mu \mathrm{m}$ before use. Salinity was reduced for the low-salinity treatments by adding ultrapure $\mathrm{H}_{2} \mathrm{O}$ (Milli- ${ }^{\circledR}{ }^{\circledR}$ ) to Vineyard Sound seawater. Tank temperatures and salinities were measured every other day, and water samples were taken weekly to determine ambient elemental ratios over the course of the experiment.

Subsamples of larvae were removed from each tank after $36 \mathrm{~h}$ for larval shell analysis. We chose this time because our goal in designing this experiment was to assess the differences in larval and juvenile shell chemistry that might affect a connectivity study. Such a study would use the first larval shell as a tag of natal habitat; if any other shell were measured, the natal habitat signature could be compromised. The remaining individuals were raised for $60 \mathrm{~d}$ under treatment conditions, with complete water changes every $2 \mathrm{~d}$. New tank water was adjusted to the appropriate temperature and salinity before larvae were added. For the first $10 \mathrm{~d}$ the larvae were allowed to swim freely in tanks. Water changes consisted of filtering out larvae through a series of mesh sieves, then returning them to the cleaned tanks. Most larvae were large, negatively buoyant pediveligers after $8 \mathrm{~d}$ in the 20 and $24^{\circ} \mathrm{C}$ tanks and after $10 \mathrm{~d}$ in the $15^{\circ} \mathrm{C}$ tanks. After $10 \mathrm{~d}$, larvae were retained within mesh sieves suspended in the tank, which restricted settlement to sieve surfaces and facilitated tank cleaning. Larvae metamorphosed into juveniles within 2 wk of spawning. Larvae and juve- niles were fed a mix of live Isochrysis sp. and concentrated algae (Instant Algae ${ }^{\complement}$ Shellfish Diet 1800) 1 to 2 times daily based on clearance rates. All treatments and tanks received the same food mixture over the course of the experiment. After $60 \mathrm{~d}$, clams were removed from their tanks and frozen until the shells were cleaned and prepared for analysis.

Sample preparation. Seawater preparation: We monitored the elemental composition of ambient seawater in the tanks during the experiment via collection of weekly water samples. The samples were vacuum filtered using acid-washed plastic Millipore ${ }^{\complement}$ brand funnels with $0.2 \mu \mathrm{m}$ cellulose nitrate membrane filters. Samples were then transferred to acid-washed HDPE bottles, acidified to $\mathrm{pH} \sim 2$ using ultrapure $\mathrm{HNO}_{3}$ (Seastar Chemicals) and refrigerated for up to 2 mo. Seawater samples were prepared for elemental analysis by diluting 50 -fold with ultrapure $2 \% \mathrm{HNO}_{3}$.

Larval shell preparation: Subsamples of roughly 1000 individual larvae were removed from each tank $36 \mathrm{~h}$ after spawning. This allowed for the larval prodissoconch I (PI) shell to set under treatment conditions, with minimal addition of post-PI shell material. Individual larvae were pooled into 1 sample vial per tank. Shells were soaked in $1 \% \mathrm{NaClO}$ (bleach) for $\sim 6 \mathrm{~h}$ to remove organic material. The cleaning solution was removed and shells were transferred to clean $0.5 \mathrm{ml}$ centrifuge tubes. Tubes were centrifuged to concentrate larval shells and then were rinsed 3 times with ultrapure $\mathrm{H}_{2} \mathrm{O}$ (Milli-Q $\left.{ }^{\circledR}\right)$. Shells were soaked in $200 \mu \mathrm{l}$ of $1 \%$ ultrapure $\mathrm{H}_{2} \mathrm{O}_{2}$ (ULTREX* II Ultrapure through VWR International) buffered to $1 \mathrm{~N}$ in ultrapure $\mathrm{NaOH}$ (EMD Chemicals through VWR International) for 5 min, then rinsed 3 times with ultrapure $\mathrm{H}_{2} \mathrm{O}$, transferred to clean acid-washed $1 \mathrm{ml}$ vials and then rinsed 4 more times. Tubes were transferred to a laminar flow hood to dry overnight. After all fluid had evaporated, $1 \mathrm{ml}$ of $2 \% \mathrm{HNO}_{3}$ was added to each vial to dissolve the shells for solution-based inductively coupled plasma-mass spectrometry (ICP-MS) analyses.

Juvenile shell preparation: Although we intended to analyze 10 juvenile clam shells per tank, this was only possible for 10 of the 24 tanks due to low survivorship. Sample sizes from the remaining 14 tanks ranged from 0 to 9 (see Table 7). Juvenile clams were placed in individual acid-washed vials using acid-washed plastic forceps and sonicated briefly to remove tissue and debris. Individuals were rinsed 3 times with ultrapure $\mathrm{H}_{2} \mathrm{O}$ and soaked for $10 \mathrm{~min}$ at $80^{\circ} \mathrm{C}$ in $1 \% \mathrm{H}_{2} \mathrm{O}_{2}$ solution buffered in $1 \mathrm{~N}$ ultrapure $\mathrm{NaOH}$ to remove organic material. Afterward, shells were rinsed 3 times with ultrapure $\mathrm{H}_{2} \mathrm{O}$, transferred to clean, acid-washed vials, rinsed 4 times with ultrapure $\mathrm{H}_{2} \mathrm{O}$, then left to dry overnight under a laminar flow hood. After the shells were dry, they were dissolved individually for solution- 
based analyses. The retained larval shell was not removed prior to dissolution of the juvenile shell because any contribution to elemental signal by the larval shell $(<0.05 \mu \mathrm{g})$ was assumed to be negligible compared to the more massive juvenile material (mean weight $=2.5 \mathrm{mg}$ ).

ICP-MS analyses. Shell material and water samples were analyzed using a Thermo-Finnigan MAT Element2 magnetic sector field inductively coupled plasma-mass spectrometer. To correct for mass bias and instrument drift, standards were run periodically during the analyses. For shell analyses, the solutionbased standards included an aragonitic otolith reference material (Yoshinaga et al. 2000) and the certified reference material (CRM) FEBS-1 (Sturgeon et al. 2005). For seawater analyses, CASS-4 Nearshore Seawater Reference Material was used as the standard (National Research Council Canada CRM).

During analyses we monitored ${ }^{25} \mathrm{Mg},{ }^{55} \mathrm{Mn},{ }^{48} \mathrm{Ca}$, ${ }^{88} \mathrm{Sr},{ }^{114} \mathrm{Cd},{ }^{138} \mathrm{Ba}$, and ${ }^{208} \mathrm{~Pb}$ in low-resolution mode. These elements were chosen because of their previous use in successful elemental tagging studies (Kalish 1989, Elsdon \& Gillanders 2002, Zacherl et al. 2003b, Bath Martin \& Thorrold 2005). Molar ratios of each element to $\mathrm{Ca}$ (hereafter E:Ca) were calculated using mass bias corrections calculated from calibration standards. Limits of detection (LOD) were calculated as the ratio of the average blank-subtracted sample intensity to $\pm 3 \mathrm{SD}$ of the blank intensity (Table 1). The intensities of ${ }^{114} \mathrm{Cd}$ were not routinely above detection limits and this element was excluded from the remaining analyses. Elemental ratios that were more than $\pm 2 \mathrm{SD}$ from the global mean were eliminated from further analysis as the anomalous values likely arose from sample contamination. This resulted in removal of $6.5 \%$ (66 of 1010) of all shell measurements and $7.4 \%$ (74 of 1001) of all seawater measurements. We also estimated precision of E:Ca during analysis of seawater, juvenile shells, and larval shells (Table 2). External precision (relative SD, \%) of the otolith reference material was calculated by dividing SD by the mean and multiplying by 100 .

Table 1. Mya arenaria. Limits of detection for elements measured during ICP-MS analyses of seawater and shell analyses. Limits were calculated as the ratio of the average blanksubtracted sample intensity to $3 \mathrm{SD}$ of the blank intensity

\begin{tabular}{|lcc|}
\hline & Seawater analyses & Shell analyses \\
\hline${ }^{25} \mathrm{Mg}$ & 10000 & 1200 \\
${ }^{48} \mathrm{Ca}$ & 700 & 10000 \\
${ }^{55} \mathrm{Mn}$ & 16 & 57 \\
${ }^{88} \mathrm{Sr}$ & 5500 & 11000 \\
${ }^{138} \mathrm{Ba}$ & 1600 & 130 \\
${ }^{206} \mathrm{~Pb}$ & 75 & 15 \\
\hline
\end{tabular}

Table 2. Mya arenaria. Number of measurements $(\mathrm{N})$ and measured precision (\% relative SD) of $\mathrm{E}: \mathrm{Ca}$ in seawater and otolith standards during analysis of seawater, juvenile shells, and larval shells

\begin{tabular}{|lrcc|}
\hline & Seawater & Juvenile shell & Larval shell \\
\hline $\mathrm{N}$ & 52 & 32 & 10 \\
$\mathrm{Mg}: \mathrm{Ca}$ & 7.9 & 2.4 & 4.8 \\
$\mathrm{Mn}: \mathrm{Ca}$ & 7.1 & 8.6 & 11.9 \\
$\mathrm{Sr}: \mathrm{Ca}$ & 0.47 & 0.31 & 0.12 \\
$\mathrm{Ba}: \mathrm{Ca}$ & 2.1 & 1.8 & 1.4 \\
$\mathrm{~Pb}: \mathrm{Ca}$ & 3.5 & 25 & 7.1 \\
\hline
\end{tabular}

Statistical analyses. Although seawater for all tanks was obtained from the same supply line, it was important to quantify any differences among tanks, as these differences may have influenced patterns in shell uptake. We used 2-way ANOVA to test for the effects of temperature and salinity on seawater $\mathrm{E}: \mathrm{Ca}$, with individual tank analyses for each week as replicates. Both temperature and salinity were treated as fixed variables. Although the same tank was sampled weekly and therefore measurements were not necessarily independent, we were unable to perform repeated-measures ANOVA because this procedure requires equal sample sizes. Instead we performed a standard ANOVA but carefully interpreted the results with the caveat that the weekly measurements may not have been independent.

Discrimination coefficients, or the ratio between Element:Ca values in carbonate and ambient water, are often used to relate seawater elemental ratios to those of carbonate (Lea \& Spero 1992). For all shell analyses, we calculated the discrimination coefficient D as

$$
\mathrm{D}=\frac{(\text { Element }: \mathrm{Ca})_{\text {carbonate }}}{(\text { Element }: \mathrm{Ca})_{\text {seawater }}}
$$

where $\mathrm{D}<1$ indicates discrimination against inclusion of the element, $\mathrm{D}=1$ suggests there is no discrimination, and D > 1 suggests elemental enrichment. We conducted all analyses for temperature and salinity effects using both elemental ratios and discrimination coefficients. Both methods yielded the same statistically significant results and we report only discrimination coefficients hereafter. Larval shell discrimination coefficients were calculated by dividing E:Ca in the shell by E:Ca for corresponding tank seawater sampled on Day 2 of the experiment. Juvenile shell discrimination coefficients were calculated by dividing the shell E:Ca by the corresponding mean tank seawater E:Ca (averaged from samples taken over the $9 \mathrm{wk}$ of the experiment). Whole-shell solution analysis of juveniles resulted in shell E:Ca values that represent an average of elemental uptake over the experiment 
and we accounted for this averaging by using tank averages of water chemistry.

We used a 3-way ANOVA to explore the effects of temperature, salinity, and stage (i.e. larval versus juvenile shell) on uptake. There were significant stage effects on discrimination coefficients $\left(p<0.01\right.$ for $D_{M g i}$ $\mathrm{p}<0.0001$ for $\mathrm{D}_{\mathrm{Mn}}, \mathrm{D}_{\mathrm{Sr}}, \mathrm{D}_{\mathrm{Ba}}, \mathrm{D}_{\mathrm{Pb}}$ idata not shown) and consequently we chose to analyze larval and juvenile shells separately using 2-way ANOVAs to test for temperature and salinity effects. We used Tukey's honestly significant difference criterion (under the multiple comparison command, implemented in Matlab v.7) to determine which group means significantly differed from one another (Hochberg \& Tamhane 1987). The use of discriminant function analyses and other multivariate statistics is widespread among studies where carbonate is used as an environmental indicator. In this study, however, we chose to use ANOVA, since we are interested in the direct effects of temperature and salinity in a controlled environment. Finally, we tested for differences between larval and juvenile uptake using simple linear correlation analysis of discrimination coefficients.

\section{RESULTS}

\section{Seawater elemental composition}

Seawater elemental composition varied among treatments (Table 3, Fig. 1). A 2-way ANOVA showed that elemental ratios significantly varied with salinity for Mg:Ca and Mn:Ca (low salinity > high salinity), and with temperature for Mn:Ca and Sr:Ca (Table 4). Seawater elemental composition also varied temporally (Fig. 1). We accounted for this variability in seawater chemistry across treatments by using discrimination coefficients, rather than elemental ratios, in subsequent analyses of larval and juvenile shells.

\section{Temperature and salinity effects on uptake}

\section{Larval shell}

Adequate numbers of larvae were harvested after $36 \mathrm{~h}$ from the majority of tanks (22 of 24) to provide shell material for elemental analyses. The samples

Table 3. Mya arenaria. Mean (SE) water temperature $\left({ }^{\circ} \mathrm{C}, \mathrm{n}=30\right)$, salinity $(\% \mathrm{o}, \mathrm{n}=30)$, dissolved Mg: $\mathrm{Ca}\left(\mathrm{mol} \mathrm{mol}^{-1}\right)$, $\mathrm{Mn}: \mathrm{Ca}(\mu \mathrm{mol}$ $\left.\mathrm{mol}^{-1}\right)$, Sr:Ca $\left(\mathrm{mmol} \mathrm{mol}^{-1}\right), \mathrm{Ba}: \mathrm{Ca}\left(\mu \mathrm{mol} \mathrm{mol}^{-1}\right)$, and $\mathrm{Pb}: \mathrm{Ca}\left(\mathrm{nmol} \mathrm{mol}^{-1}\right)$ from weekly measurements of water conditions $(\mathrm{n}=9$ for each tank). Italicized rows are treatment averages (Trtmnt)

\begin{tabular}{|c|c|c|c|c|c|c|c|c|}
\hline Tank & Temperature & Salinity & $\mathrm{Mg}: \mathrm{Ca}$ & $\mathrm{Mn}: \mathrm{Ca}$ & $\mathrm{Sr}: \mathrm{Ca}$ & $\mathrm{Ba}: \mathrm{Ca}$ & $\mathrm{Pb}: \mathrm{Ca}$ & Ca (ppm) \\
\hline 1 & $15.4(0.10)$ & $22.6(0.06)$ & $5.00(0.03)$ & $30.3(4.74)$ & $8.53(0.02)$ & $14.7(0.83)$ & $9.17(1.03)$ & $2.51(0.05)$ \\
\hline 2 & $15.5(0.10)$ & $22.6(0.07)$ & $5.03(0.02)$ & $27.5(3.80)$ & $8.52(0.02)$ & $16.9(1.54)$ & $15.9(3.40)$ & $2.44(0.08)$ \\
\hline 3 & $15.3(0.09)$ & $22.5(0.06)$ & $5.05(0.02)$ & $21.4(5.01)$ & $8.54(0.02)$ & 14.4 (1.09) & $8.61(1.46)$ & $2.88(0.23)$ \\
\hline 4 & $15.3(0.10)$ & $22.5(0.05)$ & $5.02(0.02)$ & $18.7(6.34)$ & $8.54(0.03)$ & $16.6(1.58)$ & $14.1(5.02)$ & $2.52(0.09)$ \\
\hline Trtmnt & $15.4(0.05)$ & $22.5(0.03)$ & $5.03(0.01)$ & $24.5(2.54)$ & $8.53(0.01)$ & $15.7(0.67)$ & $11.9(1.61)$ & $2.61(0.08)$ \\
\hline 5 & $15.3(0.09)$ & $30.1(0.04)$ & $5.00(0.02)$ & $20.0(5.20)$ & $8.53(0.02)$ & $15.0(0.77)$ & $10.0(2.37)$ & $3.34(0.05)$ \\
\hline 6 & $15.4(0.09)$ & $30.0(0.04)$ & $5.03(0.02)$ & $15.6(3.76)$ & $8.56(0.02)$ & $13.2(0.85)$ & $6.29(1.10)$ & $3.42(0.26)$ \\
\hline 7 & $15.4(0.09)$ & $30.0(0.05)$ & $5.03(0.02)$ & $17.9(4.09)$ & $8.55(0.03)$ & $13.0(0.61)$ & $11.6(3.74)$ & $3.36(0.25)$ \\
\hline 8 & $15.4(0.09)$ & $30.0(0.05)$ & $5.05(0.01)$ & $18.5(3.58)$ & $8.51(0.02)$ & $15.2(0.79)$ & $12.2(3.19)$ & $3.20(0.03)$ \\
\hline Trtmnt & $15.4(0.04)$ & $30.0(0.02)$ & $5.02(0.01)$ & $18.0(2.05)$ & $8.54(0.01)$ & $14.2(0.41)$ & $9.92(1.35)$ & $3.33(0.09)$ \\
\hline 9 & $19.4(0.04)$ & $22.3(0.07)$ & $5.04(0.01)$ & $17.9(3.27)$ & $8.56(0.02)$ & $15.1(1.06)$ & $10.0(1.12)$ & $2.40(0.07)$ \\
\hline 10 & $19.4(0.04)$ & $22.4(0.07)$ & $5.09(0.04)$ & $18.6(4.94)$ & $8.56(0.03)$ & 14.9 (1.38) & $15.3(4.12)$ & $2.35(0.06)$ \\
\hline 11 & $19.4(0.04)$ & $22.4(0.07)$ & $5.09(0.03)$ & $13.6(3.55)$ & $8.64(0.03)$ & $15.1(1.41)$ & $9.37(2.27)$ & $2.40(0.06)$ \\
\hline 12 & $19.5(0.04)$ & $22.3(0.05)$ & $5.05(0.02)$ & $14.7(3.98)$ & $8.57(0.03)$ & $15.1(1.19)$ & $9.32(1.53)$ & $2.38(0.06)$ \\
\hline Trtmnt & $19.4(0.02)$ & $22.4(0.03)$ & $5.06(0.01)$ & $15.2(1.78)$ & $8.58(0.01)$ & $16.4(0.76)$ & $12.1(1.22)$ & $2.38(0.03)$ \\
\hline 13 & $19.4(0.03)$ & $29.7(0.04)$ & $5.02(0.02)$ & $13.6(3.00)$ & $8.52(0.01)$ & $14.9(0.44)$ & $6.80(1.75)$ & $3.18(0.07)$ \\
\hline 14 & $19.4(0.04)$ & $29.8(0.05)$ & $5.00(0.02)$ & $15.8(4.09)$ & $8.51(0.01)$ & $15.2(1.08)$ & $9.12(2.01)$ & $3.26(0.04)$ \\
\hline 15 & $19.4(0.03)$ & $29.8(0.06)$ & $5.01(0.02)$ & $19.6(3.45)$ & $8.51(0.01)$ & $18.3(2.58)$ & $11.2(2.09)$ & $3.15(0.11)$ \\
\hline 16 & $19.4(0.03)$ & $29.8(0.06)$ & $5.02(0.01)$ & $14.9(4.13)$ & $8.53(0.01)$ & $15.2(0.91)$ & $12.0(4.03)$ & $3.34(0.07)$ \\
\hline Trtmnt & $19.4(0.02)$ & $29.8(0.02)$ & $5.02(0.01)$ & $12.3(1.53)$ & $8.59(0.01)$ & $15.1(0.33)$ & $11.2(1.50)$ & $3.23(0.04)$ \\
\hline 17 & $23.9(0.05)$ & $22.5(0.10)$ & $5.06(0.01)$ & $13.8(3.13)$ & $8.55(0.01)$ & $17.5(2.21)$ & $12.9(2.29)$ & $2.52(0.06)$ \\
\hline 18 & $23.9(0.05)$ & $22.7(0.27)$ & $5.06(0.01)$ & $16.2(4.11)$ & $8.60(0.01)$ & $16.3(1.32)$ & $9.99(1.52)$ & $2.52(0.05)$ \\
\hline 19 & $23.8(0.05)$ & $22.4(0.09)$ & $5.05(0.01)$ & $15.4(3.13)$ & $8.55(0.01)$ & $15.0(0.77)$ & $14.1(3.46)$ & $2.49(0.05)$ \\
\hline 20 & $23.9(0.05)$ & $22.4(0.09)$ & $5.05(0.02)$ & $15.5(4.25)$ & $8.61(0.01)$ & $16.8(1.75)$ & $11.5(2.26)$ & $2.49(0.05)$ \\
\hline Trtmnt & $23.9(0.02)$ & $22.5(0.08)$ & $5.07(0.01)$ & $16.2(1.92)$ & $8.58(0.02)$ & $15.1(0.61)$ & $10.9(1.25)$ & $2.50(0.03)$ \\
\hline 21 & $23.9(0.05)$ & $29.5(0.25)$ & $5.03(0.01)$ & $12.8(3.26)$ & $8.58(0.03)$ & $14.9(0.68)$ & $11.0(2.04)$ & $3.23(0.10)$ \\
\hline 22 & $23.8(0.05)$ & $29.7(0.06)$ & $5.03(0.02)$ & $11.6(3.66)$ & $8.61(0.03)$ & $14.5(0.17)$ & 8.31 (1.91) & $3.27(0.08)$ \\
\hline 23 & $24.0(0.05)$ & $29.7(0.08)$ & $5.01(0.03)$ & $12.6(2.65)$ & $8.61(0.04)$ & $15.6(1.03)$ & $9.45(2.26)$ & $3.29(0.09)$ \\
\hline 24 & $23.9(0.05)$ & $29.5(0.25)$ & $5.02(0.01)$ & $12.2(3.30)$ & $8.56(0.01)$ & $15.5(0.38)$ & $18.7(5.83)$ & $3.33(0.08)$ \\
\hline Trtmnt & $23.9(0.03)$ & $29.6(0.09)$ & $5.01(0.01)$ & $16.0(1.82)$ & $8.52(0.01)$ & $15.6(0.75)$ & $9.82(1.34)$ & $3.28(0.04)$ \\
\hline
\end{tabular}



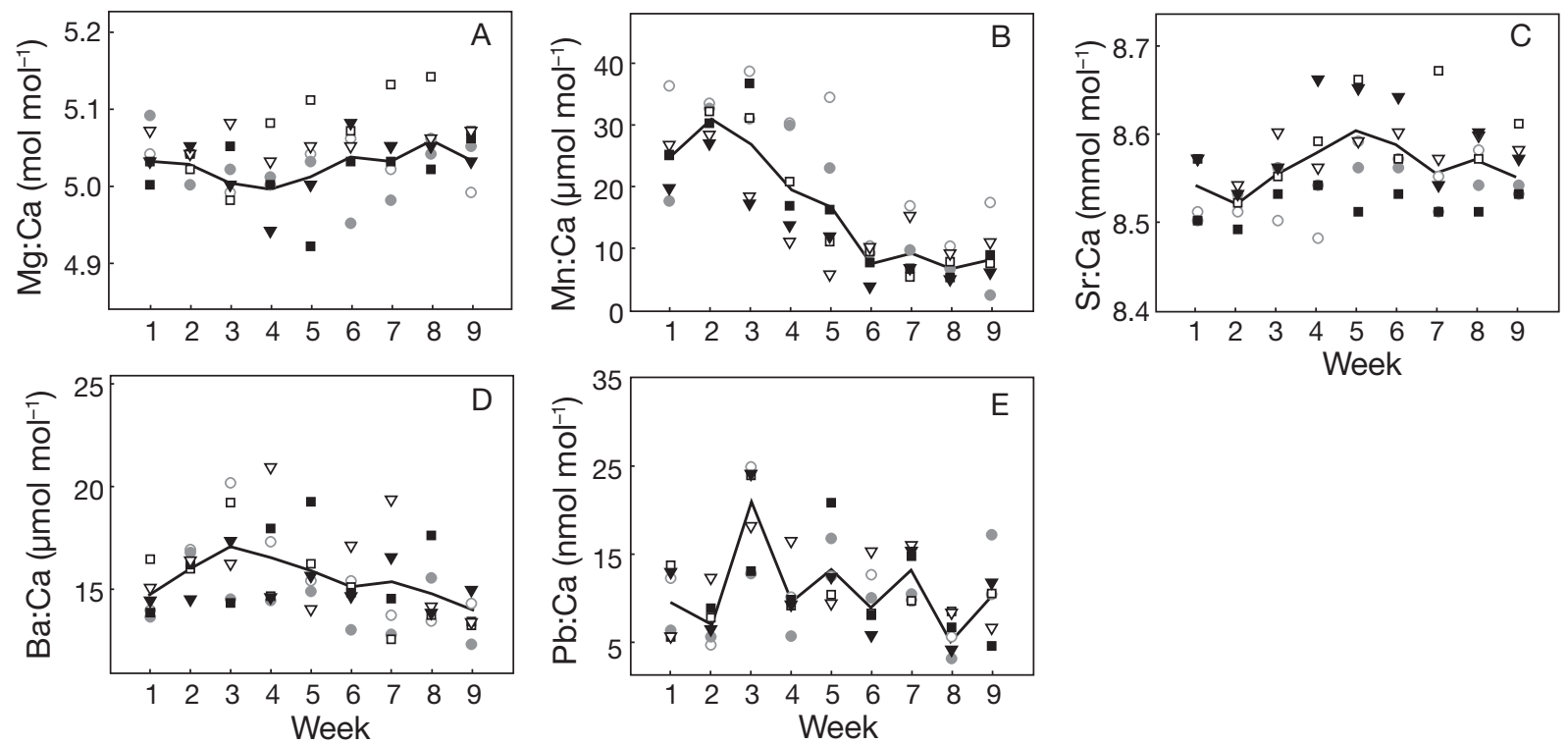

Fig. 1. Mean seawater elemental ratios (black line) for all tanks and treatments over experimental week for (A) Mg:Ca, (B) $\mathrm{Mn}: \mathrm{Ca}$, (C) Sr:Ca, (D) Ba:Ca, and (E) Pb:Ca. Symbols shown are average elemental ratios for a treatment (mean of replicate tanks). , $\mathbf{\square}$, and $\mathbf{\nabla}: 15,20$, and $24^{\circ} \mathrm{C}$ treatments, respectively. Open symbols are low-salinity treatments and closed symbols are high-salinity treatments. See Table 3 for error estimates

Table 4. Results of ANOVA testing the effects of temperature (T) and salinity (S) on dissolved elemental ratios in water sampled from the experimental tanks. Values from weekly samples in all tanks within each treatment were pooled as replicates. $F$ statistics are significant at the level of ${ }^{*} \mathrm{p}<0.01$ or ${ }^{* *} \mathrm{p}<0.001$

\begin{tabular}{|c|c|c|c|c|c|c|c|c|c|c|c|}
\hline \multirow{2}{*}{ Source } & \multirow[t]{2}{*}{$\mathrm{df}$} & \multicolumn{2}{|c|}{$\mathrm{Mg}: \mathrm{Ca}$} & \multicolumn{2}{|c|}{$\mathrm{Mn}: \mathrm{Ca}$} & \multicolumn{2}{|c|}{$\mathrm{Sr}: \mathrm{Ca}$} & \multicolumn{2}{|c|}{$\mathrm{Ba}: \mathrm{Ca}$} & \multicolumn{2}{|c|}{$\mathrm{Pb}: \mathrm{Ca}$} \\
\hline & & MS & $F$ & MS & $F$ & MS & $F$ & MS & $F$ & MS & $F$ \\
\hline $\mathrm{T}$ & 2 & $7 \times 10^{-3}$ & 2.04 & 968 & $7.62^{* *}$ & $4 \times 10^{-2}$ & $10.7^{* *}$ & 11.1 & 0.903 & 29.4 & 0.46 \\
\hline $\mathrm{S}$ & 1 & $4 \times 10^{-2}$ & $12.3^{* *}$ & 510 & $4.02^{*}$ & $1 \times 10^{-2}$ & 2.98 & 28.5 & 2.33 & 92.1 & 1.44 \\
\hline $\mathrm{T} \times \mathrm{S}$ & 2 & $8 \times 10^{-3}$ & 2.42 & 164 & 1.29 & $3 \times 10^{-2}$ & $7.02^{* *}$ & 21.0 & 1.72 & 5.51 & 0.09 \\
\hline Error & 195 & $3 \times 10^{-3}$ & & 127 & & $4 \times 10^{-3}$ & & 12.3 & & 63.9 & \\
\hline
\end{tabular}

from the remaining tanks did not provide enough shell to measure elemental ratios accurately. Across all treatments, the average $( \pm \mathrm{SE})$ larval shell elemental ratios were $3.1 \pm 0.83 \mathrm{mmol} \mathrm{mol}{ }^{-1}$ for $\mathrm{Mg}: \mathrm{Ca}, 44.8 \pm 4.1$ $\mu \mathrm{mol} \mathrm{mol}{ }^{-1}$ for $\mathrm{Mn}: \mathrm{Ca}, 2.5 \pm 0.04 \mathrm{mmol} \mathrm{mol}^{-1}$ for $\mathrm{Sr}: \mathrm{Ca}$, $3.37 \pm 0.30 \mu \mathrm{mol} \mathrm{mol}{ }^{-1}$ for $\mathrm{Ba}: \mathrm{Ca}$, and $157 \pm 17.6 \mathrm{nmol}$ $\mathrm{mol}^{-1}$ for $\mathrm{Pb}: \mathrm{Ca}$ (Table 5). Average discrimination coefficients were $<1$ for $\mathrm{D}_{\mathrm{Mg}}\left(6.2 \times 10^{-4} \pm 1.7 \times 10^{-4}\right), \mathrm{D}_{\mathrm{Sr}}$ $(0.30 \pm 0.005)$, and $\mathrm{D}_{\mathrm{Ba}}(0.24 \pm 0.02)$, and $>1$ for $\mathrm{D}_{\mathrm{Mn}}$ $(1.86 \pm 0.19)$ and $\mathrm{D}_{\mathrm{Pb}}(22.3 \pm 3.8)$.

For larval shell, ANOVA showed significant effects of temperature on $\mathrm{D}_{\mathrm{Ba}}$ and $\mathrm{D}_{\mathrm{Mn}}$, and of salinity on $\mathrm{D}_{\mathrm{Mn}}$ (Table 6, Fig. 2). There were, however, significant interaction effects for $D_{M n}$. Pairwise post hoc tests revealed that $D_{M n}$ was significantly higher in shells from the high-salinity, $15^{\circ} \mathrm{C}$ treatment than any other treatment (Fig. 3). $\mathrm{D}_{\mathrm{Ba}}$ was also significantly higher in the high-salinity, $15^{\circ} \mathrm{C}$ treatment than any other treatment, with the exception of the low-salinity $15^{\circ} \mathrm{C}$ treatment, from which it did not significantly differ. In addition, $\mathrm{D}_{\mathrm{Ba}}$ was significantly greater at $15^{\circ} \mathrm{C}$ than $20^{\circ} \mathrm{C}$ for the low-salinity treatment.

\section{Juvenile shell}

Survivorship of the juvenile clams over the course of the $60 \mathrm{~d}$ experiment was highly variable, resulting in different sample sizes for the elemental analyses. We collected juveniles from 22 of the 24 tanks, in numbers ranging from 1 to 17 per tank (Table 7 ). The average $( \pm \mathrm{SE})$ juvenile shell elemental ratios across all treatments were $0.67 \pm 0.02 \mathrm{mmol} \mathrm{mol}^{-1}$ for $\mathrm{Mg}: \mathrm{Ca}$, $14.3 \pm 0.92 \mu \mathrm{mol} \mathrm{mol}{ }^{-1}$ for $\mathrm{Mn}: \mathrm{Ca}, 1.99 \pm 0.04 \mathrm{mmol}$ $\mathrm{mol}^{-1}$ for $\mathrm{Sr}: \mathrm{Ca}, 1.52 \pm 0.11 \mu \mathrm{mol} \mathrm{mol}{ }^{-1}$ for $\mathrm{Ba}: \mathrm{Ca}$, and $4.56 \pm 0.65 \mathrm{nmol} \mathrm{mol}^{-1}$ for $\mathrm{Pb}: \mathrm{Ca}$ (Table 7). All of the average discrimination coefficients for juvenile shell were $<1\left(1.3 \times 10^{-4} \pm 1.0 \times 10^{-5}\right.$ for $\mathrm{D}_{\mathrm{Mg}}, 0.88 \pm 0.13$ for $D_{M n}, 0.23 \pm 0.003$ for $D_{S r}, 0.10 \pm 0.008$ for $D_{B a}$, and $0.45 \pm 0.13$ for $\mathrm{D}_{\mathrm{Pb}}$. 
Table 5. Mya arenaria. Larval shell elemental ratios for $\mathrm{Mg}: \mathrm{Ca}\left(\mathrm{mmol} \mathrm{mol}^{-1}\right), \mathrm{Mn}: \mathrm{Ca}\left(\mu \mathrm{mol} \mathrm{mol}^{-1}\right), \mathrm{Sr}: \mathrm{Ca}\left(\mathrm{mmol} \mathrm{mol}^{-1}\right), \mathrm{Ba}: \mathrm{Ca}$ $\left(\mu \mathrm{mol} \mathrm{mol}{ }^{-1}\right)$, and $\mathrm{Pb}: \mathrm{Ca}\left(\mathrm{nmol} \mathrm{mol}{ }^{-1}\right)$. There was insufficient carbonate to measure larval shell in Tank 4 of the $15^{\circ} \mathrm{C}$ highsalinity treatment and Tank 1 of the $20^{\circ} \mathrm{C}$ low-salinity treatment (nd: not done). -: elemental ratios that were more than $2 \mathrm{SD}$ from the global mean

\begin{tabular}{|c|c|c|c|c|c|c|c|}
\hline Temperature $\left({ }^{\circ} \mathrm{C}\right)$ & Salinity & Tank & $\mathrm{Mg}: \mathrm{Ca}$ & $\mathrm{Mn}: \mathrm{Ca}$ & $\mathrm{Sr}: \mathrm{Ca}$ & $\mathrm{Ba}: \mathrm{Ca}$ & $\mathrm{Pb}: \mathrm{Ca}$ \\
\hline \multirow[t]{4}{*}{15} & Low & 1 & 10.1 & 90.7 & 2.54 & 4.28 & 0.234 \\
\hline & & 2 & 0.799 & 53.0 & 2.33 & - & 0.158 \\
\hline & & 3 & 4.33 & 66.9 & 2.26 & 4.40 & 0.234 \\
\hline & & 4 & 1.64 & 43.8 & 2.81 & 4.27 & 0.145 \\
\hline \multirow[t]{4}{*}{15} & High & 1 & 5.25 & 60.4 & 2.45 & 5.89 & 0.282 \\
\hline & & 2 & 5.40 & 66.6 & 2.63 & 6.23 & - \\
\hline & & 3 & - & 48.5 & 2.61 & 5.42 & 0.156 \\
\hline & & 4 & nd & nd & nd & nd & nd \\
\hline \multirow[t]{4}{*}{20} & Low & 1 & nd & nd & nd & nd & nd \\
\hline & & 2 & 0.959 & 78.7 & 2.65 & 2.11 & 0.97 \\
\hline & & 3 & 1.54 & 32.7 & 2.66 & 2.80 & 0.211 \\
\hline & & 4 & 0.710 & 29.2 & 2.62 & 2.64 & 0.040 \\
\hline \multirow[t]{4}{*}{20} & High & 1 & 0.747 & 29.6 & 2.15 & 2.18 & 0.09 \\
\hline & & 2 & 1.28 & 21.9 & 2.45 & 2.70 & 0.042 \\
\hline & & 3 & 2.28 & 42.3 & 2.06 & 3.13 & 0.278 \\
\hline & & 4 & 2.28 & 42.3 & 2.06 & 3.13 & 0.278 \\
\hline \multirow[t]{4}{*}{24} & Low & 1 & 0.916 & 31.6 & 2.73 & 2.20 & 0.129 \\
\hline & & 2 & 0.754 & 25.1 & 2.78 & 1.68 & 0.035 \\
\hline & & 3 & 5.53 & - & 2.78 & 4.30 & 0.252 \\
\hline & & 4 & 0.656 & 33.6 & 2.60 & 2.76 & 0.136 \\
\hline \multirow[t]{4}{*}{24} & High & 1 & 3.65 & 42.7 & 2.66 & 3.03 & 0.126 \\
\hline & & 2 & 2.69 & 33.6 & 2.57 & 2.60 & 0.127 \\
\hline & & 3 & 15.3 & 48.4 & - & - & 0.290 \\
\hline & & 4 & 1.72 & 32.7 & 2.62 & 2.24 & 0.146 \\
\hline \multicolumn{3}{|c|}{ Average across all treatments $( \pm \mathrm{SE})$} & $3.1(0.83)$ & $44.8(4.1)$ & $2.5(0.04)$ & $3.37(0.30)$ & $157(17.6)$ \\
\hline
\end{tabular}

In juvenile shell, ANOVA showed significant effects of temperature on $\mathrm{D}_{\mathrm{Mn}}, \mathrm{D}_{\mathrm{Ba}}$ and $\mathrm{D}_{\mathrm{Pb}}$, and of salinity on $\mathrm{D}_{\mathrm{Sr}}$ (Table 6, Fig. 4). $\mathrm{D}_{\mathrm{Sr}}$ also exhibited a significant interactive effect for temperature and salinity. Pairwise post hoc tests indicated that $\mathrm{D}_{\mathrm{Mn}}$ was greater at $20^{\circ} \mathrm{C}$ than $15^{\circ} \mathrm{C}$ in the low-salinity treatment (Fig. 3). In addition, $\mathrm{D}_{\mathrm{Ba}}$ was greater at $15^{\circ} \mathrm{C}$ than $24^{\circ} \mathrm{C}$ in the lowsalinity treatment. $\mathrm{D}_{\mathrm{Pb}}$ was significantly greater at $15^{\circ} \mathrm{C}$ in the low-salinity treatment than at $24^{\circ} \mathrm{C}$ in the high-salinity treatment. $\mathrm{D}_{\mathrm{Sr}}$ did not vary consistently with temperature, but was significantly elevated in the lower salinity treatment at both $15^{\circ} \mathrm{C}$ and $24^{\circ} \mathrm{C}$.

\section{Differences between larval and juvenile shell uptake}

Tests for correlations between larval and juvenile uptake in each tank showed consistently higher dis-

Table 6. Mya arenaria. Results of ANOVA testing the effects of temperature (T) and salinity (S) on larval and juvenile discrimination coefficients. $F$ statistics are significant at the level of ${ }^{*} \mathrm{p}<0.01$ or ${ }^{* *} \mathrm{p}<0.001$

\begin{tabular}{|c|c|c|c|c|c|c|c|c|c|c|c|}
\hline \multirow[t]{2}{*}{ Source } & \multirow[t]{2}{*}{ df } & \multicolumn{2}{|c|}{$\mathrm{D}_{\mathrm{Mg}}$} & \multicolumn{2}{|c|}{$\mathrm{D}_{\mathrm{Mn}}$} & \multicolumn{2}{|c|}{$\mathrm{D}_{\mathrm{Sr}}$} & \multicolumn{2}{|c|}{$\mathrm{D}_{\mathrm{Ba}}$} & \multicolumn{2}{|c|}{$\mathrm{D}_{\mathrm{Pb}}$} \\
\hline & & MS & $F$ & MS & $F$ & MS & $F$ & MS & $F$ & MS & $F$ \\
\hline \multicolumn{12}{|c|}{ Larval shell } \\
\hline $\mathrm{T}$ & 2 & $7.3 \times 10^{-7}$ & 1.34 & 2.50 & $9.50^{*}$ & $9.9 \times 10^{-4}$ & 3.45 & 0.081 & $27.7^{* *}$ & 357 & 1.03 \\
\hline $\mathrm{S}$ & 1 & $4.4 \times 10^{-7}$ & 0.81 & 2.59 & $9.85^{*}$ & $1.0 \times 10^{-3}$ & 3.75 & $9.6 \times 10^{-3}$ & 3.26 & 537 & 1.55 \\
\hline $\mathrm{T} \times \mathrm{S}$ & 2 & $2.5 \times 10^{-7}$ & 0.46 & 2.19 & $8.33^{*}$ & $1.2 \times 10^{-3}$ & 4.06 & $7.7 \times 10^{-3}$ & 2.62 & 184 & 0.53 \\
\hline Error & 15 & $5.5 \times 10^{-7}$ & & 0.26 & & $2.9 \times 10^{-4}$ & & $2.9 \times 10^{-3}$ & & 347 & \\
\hline \multicolumn{12}{|c|}{ Juvenile shell } \\
\hline $\mathrm{T}$ & 2 & $2.3 \times 10^{-10}$ & 0.82 & 0.39 & $6.43^{*}$ & $3.4 \times 10^{-4}$ & 4.55 & $6.6 \times 10^{-3}$ & $9.24^{*}$ & 0.72 & $10.5^{*}$ \\
\hline $\mathrm{S}$ & 1 & $6.4 \times 10^{-11}$ & 0.23 & $1.0 \times 10^{-3}$ & 0.01 & $3.9 \times 10^{-3}$ & $52.2^{* *}$ & $1.0 \times 10^{-6}$ & 0.001 & 0.01 & 0.07 \\
\hline $\mathrm{T} \times \mathrm{S}$ & 2 & 0.54 & 0.54 & 0.19 & 3.14 & $6.5 \times 10^{-4}$ & $8.64^{*}$ & $8.3 \times 10^{-4}$ & 1.17 & 0.04 & 0.58 \\
\hline Error & 15 & $2.8 \times 10^{-10}$ & 0.06 & & $7.5 \times 10^{-5}$ & & $7.1 \times 10^{-4}$ & & 0.68 & & \\
\hline
\end{tabular}



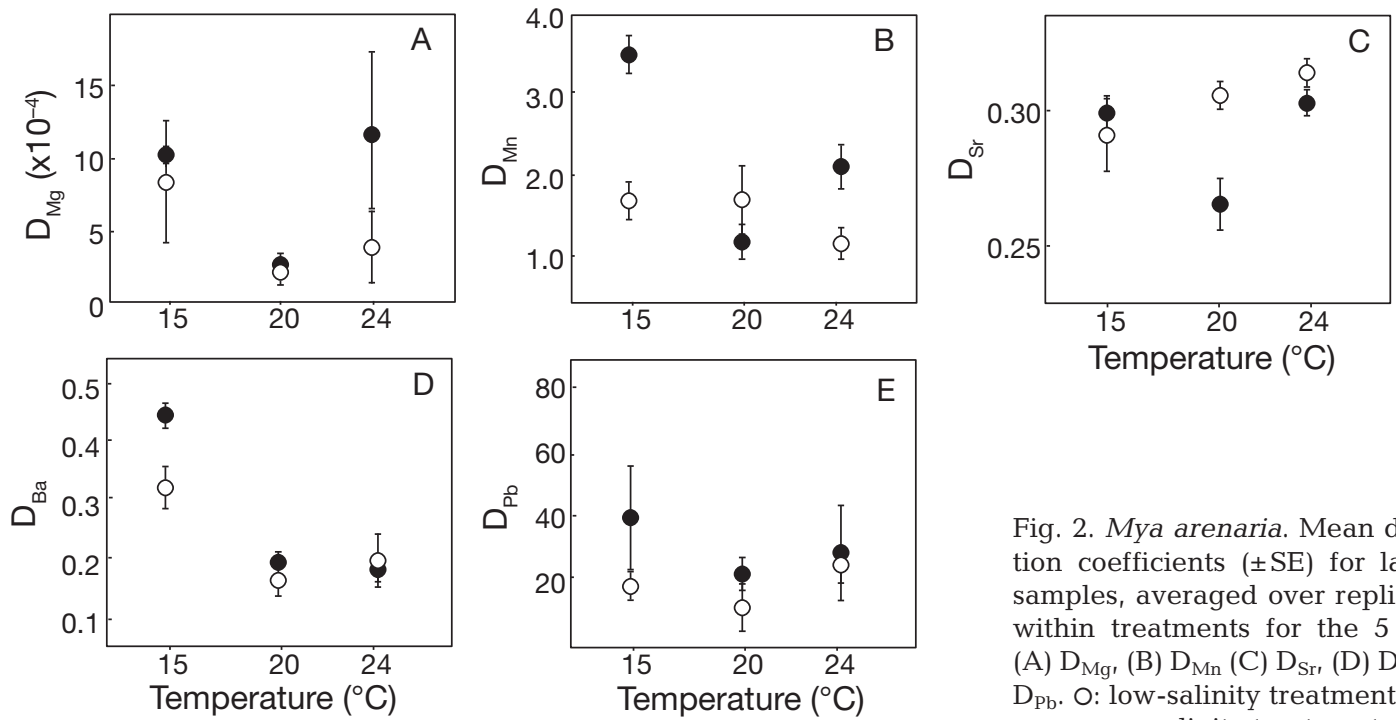

Temperature $\left({ }^{\circ} \mathrm{C}\right)$

Fig. 2. Mya arenaria. Mean discrimination coefficients $( \pm \mathrm{SE})$ for larval shell samples, averaged over replicate tanks within treatments for the 5 elements: (A) $\mathrm{D}_{\mathrm{Mg},}$ (B) $\mathrm{D}_{\mathrm{Mn}}$ (C) $\mathrm{D}_{\mathrm{Sr}}$ (D) $\mathrm{D}_{\mathrm{Ba}}$, and (E) $\mathrm{D}_{\mathrm{Pb}}$. O: low-salinity treatments; $\bullet$ : highsalinity treatments

crimination coefficients in larval than juvenile shells (Fig. 5). There was, however, little correspondence between larval and juvenile discrimination coefficients between tanks. The only coefficient that was even marginally significant was $D_{\mathrm{Ba}}(\mathrm{p}=0.02, \mathrm{r}=0.56)$; this correlation was no longer significant after Bonferroni correction at the equivalent level of $p=0.05$. All other $\mathrm{p}$ values for correlation coefficients were not signifi-

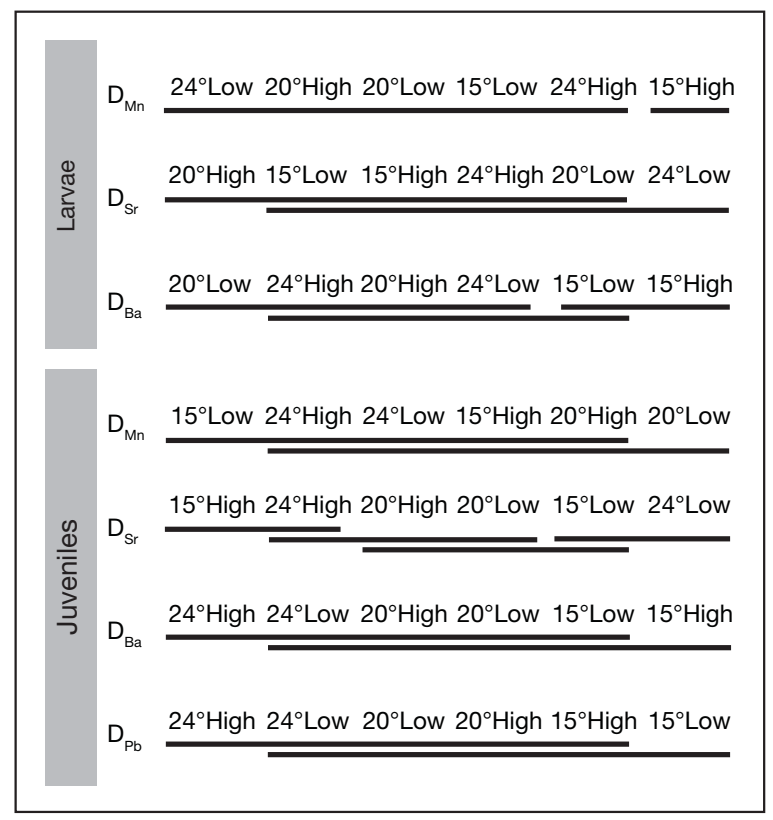

Fig. 3. Mya arenaria. Results from post-hoc pairwise comparisons tests of discrimination coefficients (D) in all treatments for larval (top) and juvenile (bottom) shells. 'High' and 'Low' refer to the high- and low-salinity treatments. Only elements with significantly different discrimination coefficients are shown cant $(p>0.50)$. The discrimination coefficient used for each tank was a single value for larvae (measured from shells pooled into a vial) and a single or average value for juveniles (calculated from 1 to 15 shells). Only tanks with values for both larvae and juveniles were used in the correlations $\left(n=18,19,19,18,19\right.$ for $D_{M g}, D_{M n}, D_{S r}$, $\mathrm{D}_{\mathrm{Ba}}$, and $\mathrm{D}_{\mathrm{Pb}}$ respectively).

\section{DISCUSSION}

We examined the effects of temperature and salinity on discrimination coefficients (and therefore uptake) in larval and juvenile bivalve shell in order to improve our ability to interpret natural variability in elemental signatures. First, we explored relations among temperature, salinity, and elemental composition of larval Mya arenaria shells. We found that uptake of Ba was affected by temperature and uptake of $\mathrm{Mn}$ was affected by temperature and salinity. Second, we compared uptake in larval and juvenile shell at various temperatures and salinities. We found significant differences between larval and juvenile discrimination coefficients for all 5 of the elements studied. Correlation analyses further indicated that there was no clear and predictable relationship between larval and juvenile discrimination coefficients with the exception of $\mathrm{D}_{\mathrm{Ba}}$. Although we expected that discrimination coefficients would differ between larval and juvenile shells, we were surprised to find that temperature and salinity influenced discrimination in shells of the 2 stages differently. Our results suggest that the ability of $M$. arenaria to discriminate against non-calcium carbonate ions increases with development. 
Table 7. Mya arenaria. Number of juvenile shells analyzed (N) and mean shell elemental ratios for $\mathrm{Mg} \mathrm{Ca}\left(\mathrm{mmol} \mathrm{mol}^{-1}\right), \mathrm{Mn}^{\mathrm{Ca}}$ $\left(\mu \mathrm{mol} \mathrm{mol}{ }^{-1}\right), \mathrm{Sr}: \mathrm{Ca}\left(\mathrm{mmol} \mathrm{mol}^{-1}\right), \mathrm{Ba}: \mathrm{Ca}\left(\mu \mathrm{mol} \mathrm{mol}^{-1}\right)$, and $\mathrm{Pb}: \mathrm{Ca}\left(\mathrm{nmol} \mathrm{mol}{ }^{-1}\right)$ for tanks. There were no survivors in Tank 4 of the $15^{\circ} \mathrm{C}$ low-salinity treatment or Tank 1 of the $24^{\circ} \mathrm{C}$ low-salinity treatment

\begin{tabular}{|c|c|c|c|c|c|c|c|c|}
\hline Temperature $\left({ }^{\circ} \mathrm{C}\right)$ & Salinity & Tank & $\mathrm{N}$ & $\mathrm{Mg}: \mathrm{Ca}$ & $\mathrm{Mn}: \mathrm{Ca}$ & $\mathrm{Sr}: \mathrm{Ca}$ & $\mathrm{Ba}: \mathrm{Ca}$ & $\mathrm{Pb}: \mathrm{Ca}$ \\
\hline 15 & Low & $\begin{array}{l}1 \\
2 \\
3 \\
4\end{array}$ & $\begin{array}{c}8 \\
2 \\
17\end{array}$ & $\begin{array}{l}0.664 \\
0.717 \\
0.651\end{array}$ & $\begin{array}{l}12.7 \\
11.1 \\
14.5\end{array}$ & $\begin{array}{l}2.20 \\
2.03 \\
2.16\end{array}$ & $\begin{array}{l}2.02 \\
1.69 \\
1.76\end{array}$ & $\begin{array}{l}11.6 \\
8.91 \\
8.30\end{array}$ \\
\hline 15 & High & $\begin{array}{l}1 \\
2 \\
3 \\
4\end{array}$ & $\begin{array}{l}4 \\
4 \\
6 \\
6\end{array}$ & $\begin{array}{l}0.750 \\
0.736 \\
0.697 \\
0.620\end{array}$ & $\begin{array}{l}21.4 \\
15.3 \\
16.5 \\
12.1\end{array}$ & $\begin{array}{l}1.88 \\
1.82 \\
1.73 \\
1.72\end{array}$ & $\begin{array}{l}2.28 \\
2.21 \\
2.00 \\
1.45\end{array}$ & $\begin{array}{l}10.4 \\
7.82 \\
3.21 \\
4.35\end{array}$ \\
\hline 20 & Low & $\begin{array}{l}1 \\
2 \\
3 \\
4\end{array}$ & $\begin{array}{c}1 \\
9 \\
10 \\
10\end{array}$ & $\begin{array}{l}0.535 \\
0.695 \\
0.716 \\
0.561\end{array}$ & $\begin{array}{l}19.8 \\
18.2 \\
22.9 \\
12.1\end{array}$ & $\begin{array}{l}2.02 \\
1.96 \\
2.08 \\
2.09\end{array}$ & $\begin{array}{c}0.983 \\
1.52 \\
1.71 \\
1.12\end{array}$ & $\begin{array}{l}4.02 \\
2.75 \\
2.67 \\
1.97\end{array}$ \\
\hline 20 & High & $\begin{array}{l}1 \\
2 \\
3 \\
4\end{array}$ & $\begin{array}{c}11 \\
4 \\
7 \\
3\end{array}$ & $\begin{array}{l}0.884 \\
0.621 \\
0.687 \\
0.687\end{array}$ & $\begin{array}{l}14.4 \\
17.0 \\
16.5 \\
19.3\end{array}$ & $\begin{array}{l}1.97 \\
1.84 \\
1.92 \\
2.00\end{array}$ & $\begin{array}{l}2.17 \\
1.66 \\
1.20 \\
1.76\end{array}$ & $\begin{array}{l}2.16 \\
3.71 \\
3.59 \\
5.21\end{array}$ \\
\hline 24 & Low & $\begin{array}{l}1 \\
2 \\
3 \\
4\end{array}$ & $\begin{array}{c}13 \\
1 \\
12\end{array}$ & $\begin{array}{l}0.727 \\
0.548 \\
0.758\end{array}$ & $\begin{array}{l}10.8 \\
10.7 \\
17.1\end{array}$ & $\begin{array}{l}2.23 \\
2.33 \\
2.23\end{array}$ & $\begin{array}{c}1.80 \\
0.876 \\
1.18\end{array}$ & $\begin{array}{l}3.39 \\
1.86 \\
2.81\end{array}$ \\
\hline 24 & High & $\begin{array}{l}1 \\
2 \\
3 \\
4\end{array}$ & $\begin{array}{l}13 \\
12 \\
10 \\
11\end{array}$ & $\begin{array}{l}0.619 \\
0.540 \\
0.655 \\
0.609\end{array}$ & $\begin{array}{l}11.1 \\
13.4 \\
6.04 \\
8.28\end{array}$ & $\begin{array}{l}1.85 \\
1.96 \\
1.92 \\
1.93\end{array}$ & $\begin{array}{l}0.951 \\
0.841 \\
0.883 \\
0.876\end{array}$ & $\begin{array}{l}1.19 \\
2.71 \\
2.62 \\
4.63\end{array}$ \\
\hline \multicolumn{4}{|c|}{ Average across all treatments $( \pm \mathrm{SE})$} & $0.67 \pm 0.02$ & $14.3 \pm 0.92$ & $1.99 \pm 0.04$ & $1.52 \pm 0.11$ & $4.56 \pm 0.65$ \\
\hline
\end{tabular}

\section{Rearing conditions}

We found a wide range of shell sizes for clams across treatments. This variability can be attributed primarily to the different experimental temperatures. Average shell lengths $( \pm \mathrm{SE})$ from 15,20 , and $24^{\circ} \mathrm{C}$ treatments were $2.57 \pm 0.13 \mathrm{~mm}, 3.10 \pm 0.11 \mathrm{~mm}$, and $5.05 \pm$ $0.21 \mathrm{~mm}$, respectively. Shell E:Ca did not vary signifi- cantly over this size range (Strasser et al. 2008); we therefore assumed that shell size differences did not affect our results.

Although every attempt was made to assure environmental conditions were consistent across tanks within treatments, we found differences in survival rates, as well as differences in seawater chemistry, among tanks. The most likely explanation for these differ-
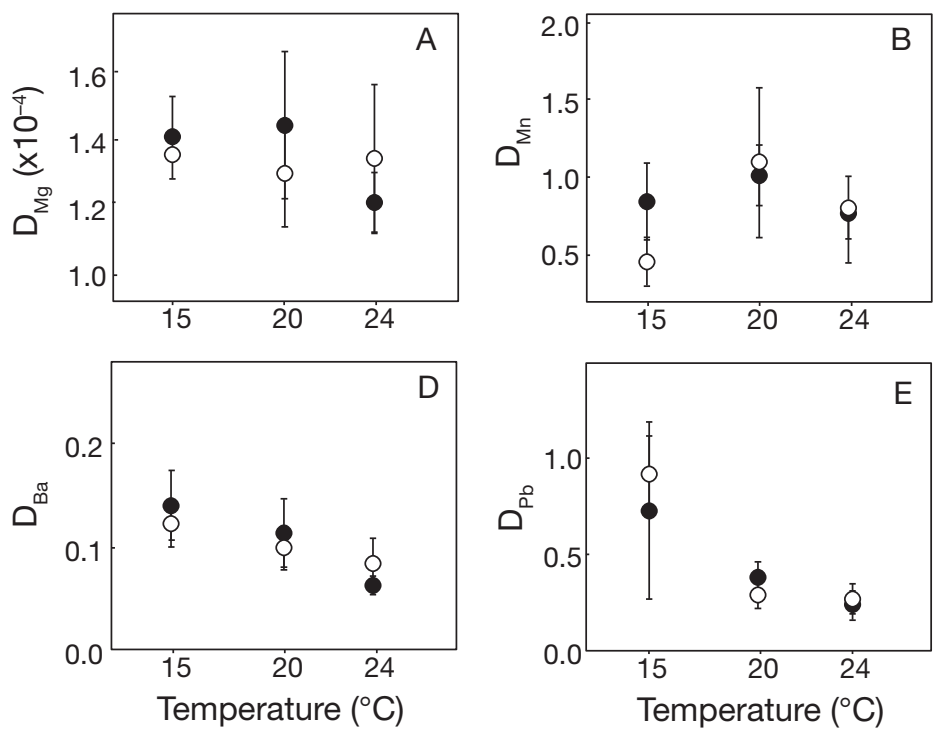

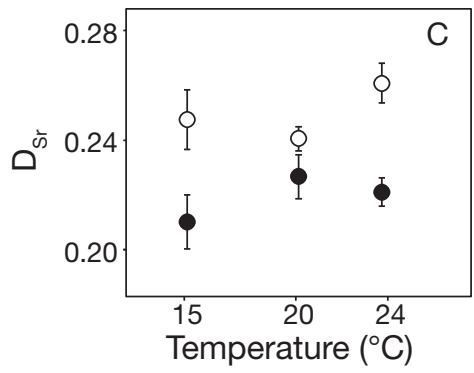

Fig. 4. Mya arenaria. Mean discrimination coefficients $( \pm \mathrm{SE})$ for juvenile shells, averaged over replicate tanks within treatments for the 5 elements: (A) $\mathrm{D}_{\mathrm{Mg}}$, (B) $\mathrm{D}_{\mathrm{Mn}}$ (C) $\mathrm{D}_{\mathrm{Sr}}$, (D) $\mathrm{D}_{\mathrm{Ba}}$ and (E) $\mathrm{D}_{\mathrm{Pb}}$. O: low-salinity treatments; high-salinity treatments 

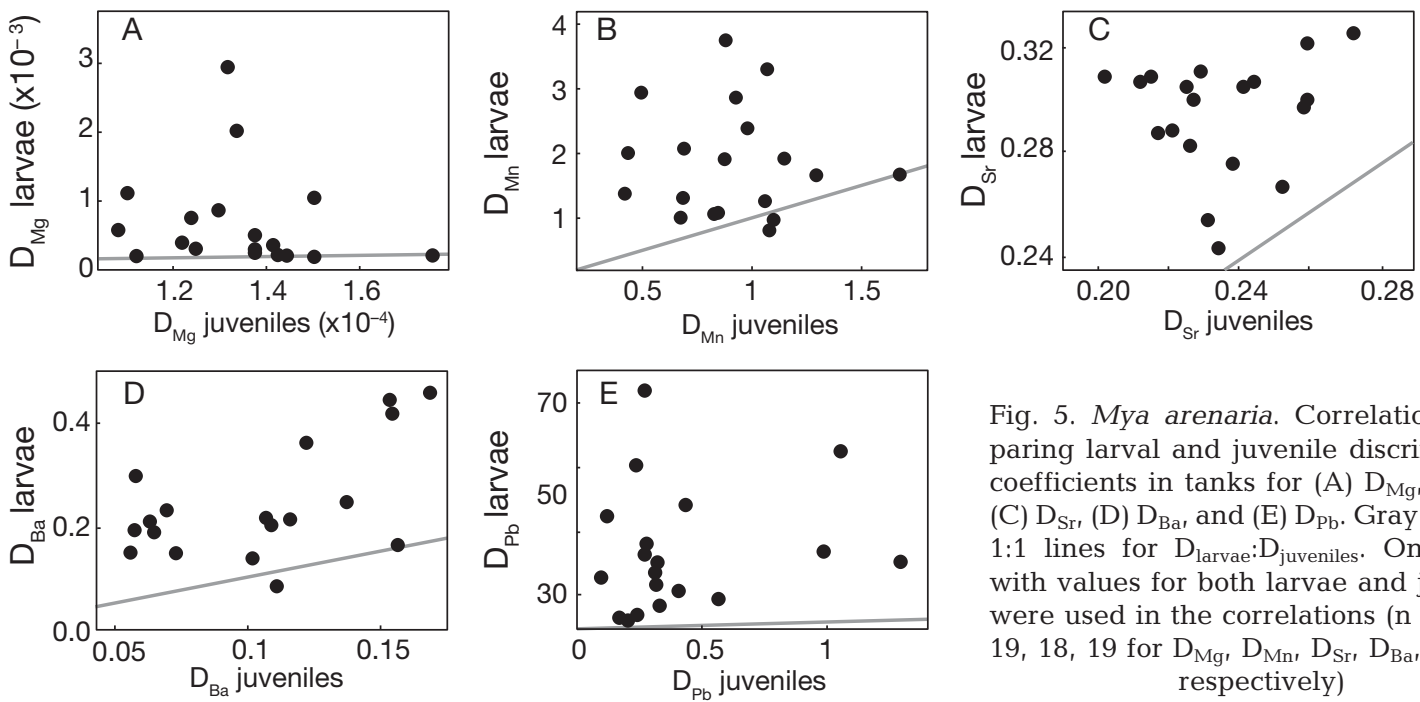

Fig. 5. Mya arenaria. Correlations comparing larval and juvenile discrimination coefficients in tanks for (A) $\mathrm{D}_{\mathrm{Mg}}$ (B) $\mathrm{D}_{\mathrm{Mn}}$ (C) $\mathrm{D}_{\mathrm{Sr}}$ (D) $\mathrm{D}_{\mathrm{Ba}}$, and (E) $\mathrm{D}_{\mathrm{Pb}}$. Gray lines are 1:1 lines for $\mathrm{D}_{\text {larvae }}: \mathrm{D}_{\text {juveniles }}$. Only tanks with values for both larvae and juveniles were used in the correlations $(n=18,19$, 19, 18, 19 for $\mathrm{D}_{\mathrm{Mg}}, \mathrm{D}_{\mathrm{Mn}}, \mathrm{D}_{\mathrm{Sr}}, \mathrm{D}_{\mathrm{Ba}}$ and $\mathrm{D}_{\mathrm{Pb}}$ respectively)

ences is the variable biological conditions among tanks. Each tank was independent from all other tanks, presumably with a unique composition of microbes, phytoplankton, and small zooplankton too small to remove from the enclosures or the clams themselves. In addition, any contamination that might have entered the tank (such as dust) may have persisted over the course of the experiment. Although we sampled the seawater weekly to quantify changes in water chemistry over time, we did not attempt to identify or quantify biological activity. This biological activity might in turn affect seawater chemistry. We accounted for this variability by performing analyses on discrimination coefficients rather than elemental ratios for shell composition.

The seawater in our low-salinity treatment tanks was prepared by diluting full-strength seawater with deionized super-pure water to achieve $22 \%$. Consequently, we assumed that elemental ratios would not vary between the 2 salinity treatments. This is not necessarily the case for low- versus high-salinity waters that Mya arenaria might encounter naturally in estuarine habitats, where freshwater runoff from continents likely affects the elemental ratios of low-salinity seawater (Burton 1976). Our results of salinity effects on shell chemistry must therefore be interpreted with this caveat in mind.

\section{Temperature and salinity effects on uptake}

$$
\text { Magnesium uptake }
$$

Our observation that neither temperature nor salinity had a significant effect on $\mathrm{D}_{\mathrm{Mg}}$ in larval or juvenile
Mya arenaria shells was in contrast to results from some previous studies of bivalve calcite (Rucker \& Valentine 1961, Dodd 1965), in which a positive correlation to temperature was reported. Lerman (1965) however, reported no effect of temperature on $\mathrm{D}_{\mathrm{Mg}}$ in oyster shells. We found no prior studies of salinity effects on $\mathrm{D}_{\mathrm{Mg}}$ in bivalve shells. Calcite and aragonite formation tend to differ in relation to solution chemistry due to their different crystal structures, even within the same organism. Lorens \& Bender (1980) hypothesized that $\mathrm{Mg}$ was regulated by mantle cells during calcite formation but not during aragonite precipitation in the shell of the bivalve Mytilus edulis. The radius of $\mathrm{Mg}^{2+}$ ions is smaller than $\mathrm{Ca}^{2+}$ ions; therefore, although $\mathrm{Mg}$ inhibits formation of calcite due to substitution for $\mathrm{Ca}^{2+}$ in the crystal lattice (Berner 1975), it is unlikely to be substituted into aragonite (Onuma et al. 1979, Speer 1983). However the extremely low discrimination coefficients we found suggest that the amount of $\mathrm{Mg}$ in shell carbonate is highly regulated by the organism during shell formation. There is some evidence that $\mathrm{Mg}: \mathrm{Ca}$ is weakly correlated to water chemistry in otolith aragonite (Wells et al. 2003), however no such studies have been conducted on bivalve aragonite. Although the mechanisms regulating discrimination of $\mathrm{Mg}$ during shell formation in $M$. arenaria remain are unresolved, temporal changes in temperature and salinity are unlikely to complicate interpretation of $\mathrm{Mg}$ signatures.

\section{Manganese uptake}

The influence of salinity on $\mathrm{D}_{\mathrm{Mn}}$ in larval compared to juvenile shells suggests that $\mathrm{Mn}$ regulation changes 
during ontogeny. Ontogenetic changes in discrimination of Mn have not been reported in other studies of biogenic carbonate, but investigations of otolith chemistry have found complex relations between $\mathrm{Mn}$ uptake and temperature and salinity. Elsdon \& Gillanders (2003) found no significant relationship between Acanthopagrus butcheri otolith and water Mn:Ca, while Bath Martin \& Thorrold (2005) reported complex temperature and salinity interactions for $\mathrm{Mn}: \mathrm{Ca}$ in Leiostromus xanthurus otoliths. The authors of the latter publication attributed their result to biological processes that might mediate the amount of biologically available $\mathrm{Mn}$ in the seawater of formation. For instance, microbial activity can contribute to the formation of Mn oxides (Sunda \& Huntsman 1987, Klinkhammer \& McManus 2001), which removes Mn ions from solution and makes relationships between $\mathrm{Mn}: \mathrm{Ca}$ in shell and seawater unpredictable.

Despite the unpredictable nature of Mn uptake, Mn has repeatedly proven useful for elemental tagging studies (e.g. Thorrold et al. 1998, 2001, Patterson et al. 2005, Becker et al. 2007). Our study suggests that experimenters should proceed with caution when including $\mathrm{Mn}$ in the suite of elements for tagging studies, due to the interactions among temperature, salinity, and biology that contribute to $\mathrm{Mn}: \mathrm{Ca}$ in aragonite. Further, salinity effects on $\mathrm{D}_{\mathrm{Mn}}$ in larval shells of estuarine species (where salinity varies on small spatial scales) may result in variable signatures for larvae within a particular site and consequent misclassification of individuals in natural tagging studies.

\section{Strontium uptake}

Our observation that temperature did not significantly affect $\mathrm{Sr}$ incorporation into larval or juvenile Mya arenaria shell contrasts with early molluscan studies generally reporting negative correlations between temperature and Sr (Dodd 1965, Hallam \& Price 1968, Thorn et al. 1995). However shells analyzed in these studies were collected from the field and the authors did not account for differences in growth rates or metabolism in their analyses. As a result, temperature-associated variation in growth rates or metabolism could have been responsible for the $D_{\text {Sr }}$ patterns rather than temperature itself. A more recent study of temperature effects on $\mathrm{Sr}$ in statoliths of the laboratory-reared cuttlefish Sepia officinalis that controlled for growth rates also reported no correlation, suggesting biological regulation of $\mathrm{Sr}$ ions outweighs the kinetic effects of temperature on $\mathrm{Sr}$ incorporation (Zumholz et al. 2007). Zacherl et al. (2003b) came to similar conclusions in their study of the gastropod Kelletia kelletii; they found that $\mathrm{Sr}$ :Ca correlated posi- tively with temperature in protoconchs and negatively in larval statoliths. They concluded that there are strong biological controls on $\mathrm{Sr}$ incorporation into aragonite, likely due to the differential discrimination of $\mathrm{Sr}$ across different biological membranes responsible for statolith and protoconch production.

There is less ambiguity in the literature for the relationship between Sr uptake into molluscan calcium carbonate and salinity. The most commonly reported result is a lack of correlation (Dodd 1965, Hallam \& Price 1968, Stecher et al. 1996, Zumholz et al. 2007), as we found in our larval shells. Because the low-salinity treatment was achieved by diluting seawater with ultrapure water, we did not expect to detect differences in Sr:Ca among treatments. However, we found $\mathrm{D}_{\mathrm{Sr}}$ significantly differed with salinity for juvenile shells, which suggests that Sr concentration in ambient water, as well as $\mathrm{Sr}$ Ca ratios, influenced uptake of Sr into juvenile shells. A similar result has been found with otoliths (Fowler et al. 1995, Bath Martin \& Thorrold 2005).

Our data suggest that molluscan $\mathrm{Sr}$ : Ca ratios in aragonite of shells are influenced by physiology, although the exact mechanism is unknown. There is evidence in the literature that $\mathrm{Sr}$ uptake is dependent upon calcification rates in aragonitic mollusc shells (Purton et al. 1999, Takesue \& van Geen 2004). Any factor that affects calcification rates could, therefore, influence the interpretation of trends in $\mathrm{Sr}$ :Ca in shell (Likins et al. 1963, Stecher et al. 1996, Carre et al. 2006). This may explain reports that temperature, which is often positively correlated with growth rate, influences $\mathrm{Sr}$ uptake. Gillikin et al. (2005), however, carefully documented the relationship between environmental factors and Sr uptake in 2 species of marine bivalves with aragonitic shells and concluded that $\mathrm{Sr}$ :Ca ratios in shell are regulated by biological processes rather than thermodynamics. Studies of growth rate effects on $\mathrm{Sr}$ incorporation into Мya arenaria juvenile shell have produced both positive and negative correlations to growth rate for juvenile shells reared in the same conditions (Strasser et al. 2008). These ambiguous results lend support to the idea that $\mathrm{Sr}$ incorporation may involve a number of physical and biological processes. One example of a process that might influence $\mathrm{Sr}$ incorporation is entrapment of material on the surface of the crystal during carbonate formation. Recent studies suggest that elemental fractionation in inorganic calcite (Watson 2004) and aragonite (Gaetani \& Cohen 2006) is dominated by non-equilibrium processes, including surface entrapment. Indeed, with more study, surface entrapment may provide a powerful unifying mechanism for explaining apparently divergent behavior of $\mathrm{Sr}: \mathrm{Ca}$ in fish otoliths, bivalve shells, and coral skeletons. 
Barium and lead uptake

We found evidence for a negative correlation between temperature and $\mathrm{D}_{\mathrm{Ba}}$ in both larval and juvenile shells, which is consistent with results of Zacherl et al. (2003b) and Zumholz et al. (2007), who both found a negative correlation in the aragonite structures of laboratory-reared molluscans. We found no significant relationship between $\mathrm{D}_{\mathrm{Ba}}$ and salinity, which is also consistent with results from Zumholz et al. (2007). Ba is likely to be a useful addition to elemental tagging studies, even in situations where its concentration does not vary spatially, as uptake into molluscan shell appears to have a consistent relationship with temperature.

Larval shell $\mathrm{D}_{\mathrm{Pb}}$ did not vary significantly with temperature, although juvenile shell $\mathrm{D}_{\mathrm{Pb}}$ showed evidence of a significant negative correlation. Previous research generally has shown that clams incorporate $\mathrm{Pb}$ into their shells in relation to ambient water concentrations (Babukutty \& Chacko 1992, Pitts \& Wallace 1994, Almeida et al. 1998, Boisson et al. 1998); however, these studies did not examine the relationship at different temperatures or salinities. More recently Mubiana $\&$ Blust (2007) showed that Pb uptake into soft tissue is positively correlated to temperature, but they did not examine the effects of temperature on $\mathrm{Pb}$ uptake into shell. It is difficult to discern the underlying causes of the significant relationship between temperature and juvenile shell $\mathrm{D}_{\mathrm{Pb}}$ that we found. Therefore, studies using trace metals as part of unique geochemical signatures should be cautious until there is more information about discrimination coefficients at variable temperatures and salinities.

\section{Differences in larval and juvenile uptake}

We found highly significant differences between uptake in larval and juvenile Mya arenaria shells. In addition, larval and juvenile discrimination coefficients were not significantly correlated for 4 of the 5 elements studied, suggesting that the physiological mechanisms influencing uptake are quite different for the 2 stages. Not only do discrimination coefficients change with ontogeny, but the effects of environmental conditions on discrimination coefficients change as well. The one exception we found was for $\mathrm{D}_{\mathrm{Ba}}$ although we found that the correlation was no longer significant after Bonferroni correction, the correlation appears to be real (Fig. 5) and we therefore assume it would become significant at larger sample sizes. $\mathrm{D}_{\mathrm{Ba}}$ correlated positively between larvae and juveniles, suggesting that incorporation of $\mathrm{Ba}$ into shell is not as affected by ontogeny as the other elements in this study. This may be because $\mathrm{Ba}$ is not known to be a critical element in shell construction, nor is it harmful to the organism when present in the extrapallial fluid. Ba:Ca in biogenic carbonate is therefore likely to reflect ambient levels.

The differences between larval and juvenile shell discrimination coefficients are not surprising given the disparate mechanisms that produce larval and juvenile shell in bivalves. Production of the first larval shell, or prodissoconch I, starts by evagination of a shell gland and subsequent spreading of the shell field. Prodissoconch II formation begins after the 2 valves surround the body and close against each other (Waller 1981). Early in prodissoconch I formation, the shell gland transitions into the mantle structure, which is responsible for shell production thereafter (Waller 1981). These intense morphological and developmental changes occurring during PI production are likely to cause significant differences in elemental uptake compared to juvenile shell production when the mantle has formed completely. Our results lend support to the idea that the effects of physiology on larval and juvenile shell production are sufficiently different to affect uptake and incorporation of elements into carbonate.

In a study of $\mathrm{Mg}$ and $\mathrm{Sr}$ concentrations in nautilus shells, Mann (1992) found consistently higher and more variable elemental concentrations in carbonate formed earlier in life. Three possible explanations are given: (1) an age-related change in biomineralization, wherein elemental concentrations depend on carbonate accretion rates; (2) maturation of the biomineralization system, which results in increased control over shell chemistry; or (3) larvae are exposed to stresses related to food acquisition and protection-stresses less problematic in older organisms. Given the evidence that growth rate affects elemental incorporation (Onuma et al. 1979, Purton et al. 1999, Sinclair 2005) and the fact that different processes are involved in larval and juvenile shell accretion, it is plausible that any or all of these ontogenetic explanations are applicable to our data.

Larval discrimination coefficients tended to be closer to 1 than juvenile discrimination coefficients for all elements (Fig. 5). This result suggests that the more advanced development of juveniles compared to larvae results in a greater ability to discriminate against ions that are not $\mathrm{Ca}^{2+}$ during shell production. Hirao et al. (1994) suggested that $\mathrm{Pb}$ content in abalone Haliotis shells decreased due to the development of a physiological mechanism for $\mathrm{Pb}$ exclusion that becomes more efficient with age. Bivalve shell composition is influenced by the efficiency of the $\mathrm{Ca}^{2+}$ channel that transports ions into the extrapallial fluid for shell construction, as well as the ability to discriminate against non- $\mathrm{Ca}^{2+}$ ions (Carre et al. 2006). Although there are no data published on differences in channel function 
for larval and juvenile molluscs, large changes in morphology and cell function during PI production may influence the composition of the fluid from which the shell is precipitated.

\section{CONCLUSIONS}

Results from analyses such as ours are crucial to studies that rely on biogenic carbonate to indicate either natal habitat or past environmental conditions. Temperature and salinity effects on discrimination coefficients of any element can be beneficial for connectivity studies wherein temperature and salinity vary geographically while ambient concentrations of the element itself does not. However this tool is useful only if the study focuses on a single cohort or if temperature and salinity conditions do not vary over time. In contrast, temperature and salinity influences on discrimination coefficients complicate interpretations when variation in shell elemental composition is used as a recorder of past elemental concentrations in water or in natural tagging studies when biogenic carbonate potentially formed outside of the spawning time frame is used to identify natal habitats (e.g. Becker et al. 2007).

We found that temperature and salinity significantly influenced shell chemistry of larval and juvenile Mya arenaria. However, physiological processes, whether influenced by ontogeny or environmental conditions, have the potential to complicate interpretations of elemental composition in biogenic carbonates. Therefore, care must be taken to understand the potentially confounding effects of physiology before shell chemistry is used in studies as a proxy for environment or to identify natal habitat for connectivity studies.

Acknowledgements. This work was supported by NSF project numbers OCE-0241855 and OCE-0215905. We thank H. Lind of the Eastham Natural Resources Department and P. Alatalo of WHOI for helpful aquaculture advice and suggestions. We also thank T. Marcotti for providing spawning stock. V. Starczak was helpful with statistical procedures and data interpretation. B. Walther and T. Elsdon were important resources for experimental design and implementation, as well as for helpful discussion of the manuscript. We also thank D. Adams, S. Beaulieu, I. Garcia-Berdeal and S. Mills for comments on early drafts.

\section{LITERATURE CITED}

Almeida MJ, Machado J, Moura G, Azevedo M, Coimbra J (1998) Temporal and local variations in biochemical composition of Crassostrea gigas shells. J Sea Res 40:233-294

- Arai T, Maeda M, Yamakawa H, Kamatani A, Ohji M, Miyazaki N (2003) Uptake and elimination of trace metals in shells of abalones Haliotis spp. Bull Environ Contam Toxicol 71:75-82
Arkhipkin AI, Campana SE, FitzGerald J, Thorrold SR (2004) Spatial and temporal variation in elemental signatures of statoliths from the Patagonian longfin squid (Loligo gahi). Can J Fish Aquat Sci 61:1212-1224

Babukutty Y, Chacko J (1992) Trace metals in an estuarine bivalve from the southwest coast of India. Ambio 21: 292-296

Bath GE, Thorrold SR, Jones CM, Campana SE, McLaren JW, Lam JWH (2000) Strontium and barium uptake in aragonitic otoliths of marine fish. Geochim Cosmochim Acta 64: 1705-1714

Bath Martin G, Thorrold SR (2005) Temperature and salinity effects on magnesium, manganese, and barium incorporation in otoliths of larval and early juvenile spot Leiostomus xanthurus. Mar Ecol Prog Ser 293:223-232

> Bath Martin G, Thorrold SR, Jones CM (2004) Temperature and salinity effects on strontium incorporation in otoliths of larval spot (Leiostomus xanthurus). Can J Fish Aquat Sci 61:34-42

Becker BJ, Fodrie FJ, McMillan P, Levin LA (2005) Spatial and temporal variation in trace elemental fingerprints of mytilid mussel shells: a precursor to invertebrate larval tracking. Limnol Oceanogr 50:48-61

Becker BJ, Levin LA, Fodrie FJ, McMillan PA (2007) Complex larval connectivity patterns among marine invertebrate populations. Proc Natl Acad Sci USA 104:3267-3272

Berner RA (1975) The role of magnesium in the crystal growth of calcite and aragonite from sea water. Geochim Cosmochim Acta 39:489-494

> Boisson F, Cotret O, Fowler SW (1998) Bioaccumulation and retention of lead in the mussel Mytilus galloprovincialis following uptake from seawater. Sci Total Environ 222: $55-61$

Bowden KF (1980) Physical factors: salinity, temperature, circulation, and mixing processes. In: Olausson E, Cato I (eds) Chemistry and biogeochemistry of estuaries. WileyInterscience, New York, p 37-70

Burton JD (1976) Basic properties and processes in estuarine chemistry. In: Burton JD, Liss PS (eds) Estuarine Chemistry. Academic Press, London, p 1-31

Campana SE (1999) Chemistry and composition of fish otoliths: pathways, mechanisms and applications. Mar Ecol Prog Ser 188:263-297

Campana SE, Thorrold SR (2001) Otoliths, increments, and elements: keys to a comprehensive understanding of fish populations? Can J Fish Aquat Sci 58:30-38

> Carre M, Bentaleb I, Bruguier O, Ordinola E, Barrett NT, Fontugne M (2006) Calcification rate influence on trace element concentrations in aragonitic bivalve shells: evidences and mechanisms. Geochim Cosmochim Acta 70: 4906-4920

DiBacco C, Levin LA (2000) Development and application of elemental fingerprinting to track the dispersal of marine invertebrate larvae. Limnol Oceanogr 45:871-880

> Dodd JR (1965) Environmental control of strontium and magnesium in Mytilus. Geochim Cosmochim Acta 29:385-398

Dodd JR (1967) Magnesium and strontium in calcareous skeletons: a review. J Paleo 41:1313-1329

$>$ Dodd JR, Crisp EL (1982) Non-linear variation with salinity of $\mathrm{Sr} / \mathrm{Ca}$ and $\mathrm{Mg} / \mathrm{Ca}$ ratios in water and aragonitic bivalve shells and implications for paleosalinity studies. Palaeogeogr Palaeoclimatol Palaeoecol 38:45-56

Elsdon TS, Gillanders BM (2002) Interactive effects of temperature and salinity on otolith chemistry: challenges for determining environmental histories of fish. Can J Fish Aquat Sci 59:1796-1808

Elsdon TS, Gillanders BM (2003) Relationship between water 
and otolith elemental concentrations in juvenile black bream Acanthopagrus butcheri. Mar Ecol Prog Ser 260: 263-272

Fowler AJ, Campana SE, Jones CM, Thorrold SR (1995) Experimental assessment of the effect of temperature and salinity on elemental composition of otoliths using solution-based ICPMS. Can J Fish Aquat Sci 52:1421-1430

Gaetani GA, Cohen AL (2006) Element partitioning during precipitation of aragonite from seawater: a framework for understanding paleoproxies. Geochim Cosmochim Acta 70:4617-4634

Gillikin DP, Lorrain A, Navez J, Taylor JW and others (2005) Strong biological controls on $\mathrm{Sr} / \mathrm{Ca}$ ratios in aragonitic marine bivalve shells. Geochem Geophys Geosyst 6: Q05009

$>$ Hallam A, Price NB (1968) Environmental and biochemical control of strontium in shells of Cardium edule. Geochim Cosmochim Acta 32:319-328

Hirao Y, Matsumoto A, Yamakawa H, Maeda M, Kimura K (1994) Lead behavior in abalone shell. Geochim Cosmochim Acta 58:3183-3189

Hochberg Y, Tamhane AC (1987) Multiple comparisons procedures. John Wiley \& Sons, New York

Hoff GR, Fuiman LA (1995) Environmentally induced variation in elemental composition of red drum (Sciaenops ocellatus) otoliths. Bull Mar Sci 56:578-591

Kalish JM (1989) Otolith microchemistry: validation of the effects of physiology, age and environment on otolith composition. J Exp Mar Biol Ecol 132:151-178

Klinkhammer GP, McManus J (2001) Dissolved manganese in the Columbia River Estuary: production in the water column. Geochim Cosmochim Acta 65:2835-2841

Lazareth CE, Vander Putten E, Andre L, Dehairs F (2003) High-resolution trace element profiles in shells of the mangrove bivalve Isognomon ephippium: a record of environmental spatio-temporal variations? Estuar Coast Shelf Sci 57:1103-1114

Lea D, Spero HJ (1992) Experimental determination of barium uptake in shells of the planktonic foraminifera Orbulina unviersa at $22^{\circ} \mathrm{C}$. Geochim Cosmochim Acta 56: $2673-2680$

Lerman A (1965) Strontium and magnesium in water and Crassostrea calcite. Science 150:745-746

Levin LA (2006) Recent progress in understanding larval dispersal: new directions and digressions. Integr Comp Biol 46:282-297

Likins RC, Berry EG, Posner AS (1963) Comparative fixation of calcium and strontium by snail shell. Ann N Y Acad Sci 109:269-277

Lorens RB, Bender ML (1980) The impact of solution chemistry on Mytilus edulis calcite and aragonite. Geochim Cosmochim Acta 44:1265-1278

Mann KO (1992) Physiological, environmental, and mineralogical controls on $\mathrm{Mg}$ and $\mathrm{Sr}$ concentrations in Nautilus. J Paleontol 66:620-636

Moilanen A, Nieminen M (2002) Simple connectivity measures in spatial ecology. Ecology 83:1131-1145

Mubiana VK, Blust R (2007) Effects of temperature on scope for growth and accumulation of $\mathrm{Cd}, \mathrm{Co}, \mathrm{Cu}$ and $\mathrm{Pb}$ by the marine bivalve Mytilus edulis. Mar Environ Res 63: 219-235

Onuma N, Masuda F, Masataka H, Wada K (1979) Crystal structure control on trace element partition in molluscan shell formation. Geochem J 13:187-189

Palumbi SR (2003) Population genetics, demographic connectivity, and the design of marine reserves. Ecol Appl 13: $146-158$
Patterson HM, Kingsford MJ, McCulloch MT (2005) Resolution of the early life history of a reef fish using otolith chemistry. Coral Reefs 24:222-229

Pitts LC, Wallace GT (1994) Lead deposition in the shell of the bivalve, Mya arenaria: an indicator of dissolved lead in seawater. Estuar Coast Shelf Sci 39:93-104

> Purton LMA, Shields GA, Brasier MD, Grime GW (1999) Metabolism controls Sr/Ca ratios in fossil aragonitic mollusks. Geology 27:1083-1086

Rucker JB, Valentine JW (1961) Salinity response of trace element concentration in Crassostrea virginica. Nature 190: 1099-1100

Shanks AL, Grantham BA, Carr MH (2003) Propagule dispersal distance and the size and spacing of marine reserves. Ecol Appl 13:159-169

Sinclair DJ (2005) Correlated trace element 'vital effects' in tropical corals: a new geochemical tool for probing biomineralization. Geochim Cosmochim Acta 69:3265-3284

Speer JA (1983) Crystal chemistry and phase relations of orthorhombic carbonates. In: Reeder RJ (ed) Carbonates: mineralogy and chemistry, Vol 11. Mineralogy Society of America, Washington, DC

Stecher HA, Krantz DE, Lord CJ III, Luther GW III, Bock KW (1996) Profiles of strontium and barium in Mercenaria mercenaria and Spisula solidissima shells. Geochim Cosmochim Acta 60:3445-3456

Strasser CA, Mullineaux LS, Walther BD (2008) Growth rate and age effects on Mya arenaria shell chemistry: implications for biogeochemical studies. J Exp Mar Biol Ecol 355: 153-163

Sturgeon RE, Willie SN, Yang L, Greenberg R and others (2005) Certification of a fish otolith reference material in support of quality assurance for trace element analysis. J Anal At Spectrom 10:1067-1071

Sunda WG, Huntsman SA (1987) Microbial oxidation of manganese in a North Carolina estuary. Limnol Oceanogr 32: $552-564$

Takesue RK, van Geen A (2004) Mg/Ca, Sr/Ca, and stable isotopes in modern and Holocene Protothaca staminea shells from a northern California coastal upwelling region. Geochim Cosmochim Acta 68:3845-3861

Thorn K, Cerrato RM, Rivers ML (1995) Elemental distributions in marine bivalve shells measured by synchrotron X-ray fluorescence. Biol Bull 188:57-67

> Thorrold SR, Jones CM, Swart PK, Targett TE (1998) Accurate classification of juvenile weakfish Cynoscion regalis to estuarine nursery areas based on chemical signatures in otoliths. Mar Ecol Prog Ser 173:253-265

Thorrold SR, Latkoczy C, Swart PK, Jones CM (2001) Natal homing in a marine fish metapopulation. Science 291: 297-299

Thorrold SR, Jones GP, Hellberg ME, Burton RS and others (2002) Quantifying larval retention and connectivity in marine populations with artificial and natural markers. Bull Mar Sci 70:291-308

Thorson G (1950) Reproductive and larval ecology of marine bottom invertebrates. Biol Rev Camb Philos Soc 25:1-45

Thorson G (1966) Some factors influencing the recruitment and establishment of marine benthic communities. Neth J Sea Res 3:267-293

Vander Putten E, Dehairs F, Keppens E, Baeyens W (2000) High resolution distribution of trace elements in the calcite shell layer of modern Mytilus edulis: Environmental and biological controls. Geochim Cosmochim Acta 64:997-1011

Waller TR (1981) Functional morphology and development of veliger larvae of the European oyster, Ostrea edulis L. Smithson Contrib Zool 328:1-70 
Watson EB (2004) A conceptual model for near-surface kinetic controls on the trace-element and stable isotope composition of abiogenic calcite crystals. Geochim Cosmochim Acta 68:1473-1488

Wells BK, Rieman BE, Clayton JL, Horan DL, Jones CM (2003) Relationships between water, otolith, and scale chemistries of westslope cutthroat trout from the Coeur d'Alene River, Idaho: the potential application of hard-part chemistry to describe movements in freshwater. Trans Am Fish Soc 132:409-424

Wilbur KM (1972) Shell formation in mollusks. In: Florkin M, Scheer BT (eds) Chemical zoology Vol VII: Mollusca. Academic Press, New York, p 103-145

Yoshinaga J, Nakama A, Morita M, Edmonds JS (2000) Fish

Editorial responsibility: Paul Snelgrove,

St. Johns, Newfoundland, Canada otolith reference material for quality assurance of chemical analyses. Mar Chem 69:91-97

Zacherl DC, Manriquez PH, Paradis G, Day RW and others (2003a) Trace elemental fingerprinting of gastropod statoliths to study larval dispersal trajectories. Mar Ecol Prog Ser 248:297-303

Zacherl DC, Paradis G, Lea DW (2003b) Barium and strontium uptake into larval protoconchs and statoliths of the marine neogastropod Kelletia kelletii. Geochim Cosmochim Acta 67:4091-4099

Zumholz K, Hansteen TH, Piatkowski U, Croot PL (2007) Influence of temperature and salinity on the trace element incorporation into statoliths of the common cuttlefish (Sepia officinalis). Mar Biol 151:1321-1330

Submitted: January 16, 2008; Accepted: July 21, 2008 Proofs received from author(s): October 15, 2008 